\title{
Patients' Satisfaction and its determinants in Outpatient Department of Deberebirhan Referral Hospital, North Shoa, Ethiopia
}

Rahel Mezemir', Darye Getachew ${ }^{1}$ and Measho Gebreslassie ${ }^{2 *}$

${ }^{1}$ Department of Nursing, College of Medicine and Health Sciences, University of Gondar, Ethiopia

${ }^{2}$ Department of Health Service Management and Health Economics, Institute of Public Health, University of Gondar, Gondar, Ethiopia

\begin{abstract}
Introduction: Patient satisfaction is a primary means of measuring the effectiveness of healthcare delivery Patients have explicit desires for quality services when they visit health institutions. However, inadequate discovery of their needs may result in patient dissatisfaction. Hence, this study aimed to determine the level and determinants of patient satisfaction with outpatient department of Deberebirhan referral hospital, North Shoa, Ethiopia

Methods: Institution based cross sectional study was conducted from April 1-30,2013. Systematic random sampling technique was used to get a total of 414 outpatient clients/service users/. Data was collected using pretested, structured and interviewer administered questionnaire, and it was analyzed using SPSS version 20. Both Bivariate and multivariate logistic regression were computed to identify the associated factors.

Results: The overall patient's satisfaction in health care services rendered at Deberebirhan Referral Hospital was $57.7 \%$. Majority of the patients were satisfied with the quality of medical instruments $368(88.9 \%)$. On the contrary, Majority of the patients were not satisfied with the availability of drinking water $320(77.3 \%)$. Provision of prescribed drugs [AOR: 4.304(1.139-14.606)], older age [AOR: 3.353(1.628-6.905)], higher educational status [AOR: 0.392(0.188-0.818)] and those who were not charged for service[AOR: $2.510(1.518-4.150)]$ were significantly associated with patient satisfaction.

Conclusion and recommendation: The overall patient's satisfaction in Deberebirhan referral hospital was relatively high. However, lack of drugs and supplies, and long waiting time were found to be the major causes of dissatisfaction. Therefore, the Hospital management should understand these service areas and plan for a better service delivery.
\end{abstract}

Keywords: Outpatient; Satisfaction; Hospital; Deberebirhan

\section{Introduction}

Patient satisfaction is one of the main components of quality of care which includes respect for the patient and understanding the need of patient and providing services accordingly [1]. Hospitals are an important part of any health system. To achieve service excellence, hospitals require continuous efforts to improve quality of the service delivery system [2-6]. Patient satisfaction and perceived quality service will influence utilization of services, as well as compliance with practitioner recommendations [7]. If the system cannot be trusted to guarantee a threshold level of quality, it will remain underutilized, be bypassed, used only for minor ailments, or used as a measure of last resort [8].

Measuring patient satisfaction has become an integral part of hospital management strategies across the globe. Moreover, the quality assurance an accreditation process in most countries requires regular measurement of patient satisfaction [9]. As many researchers revealed, patient satisfaction represent a key indicator for the quality of health care delivery and this internationally accepted factor needs to be studied repeatedly for the good function of the health care system $[10,11]$.

The Ethiopian federal ministry of health has been running a sector wide reform effort aimed at significantly improving the quality and the accessibility of the service at all levels of the country through implementing hospital reform guideline. One of the component of this guideline is improving service quality, this can be achieved by caring out of survey on patient satisfaction on the regular base [12].

Besides, improving quality service is one of strategies to reduce the burden of communicable disease and play a significant role in attaining the millennium Development goal (MDGs) [13]. Studies in the developing world have shown a clear link between patient satisfaction and variety explanatory factor, among which service quality has been prominent [14]. This link is also important in the health sector Ethiopia [14]. This study intends to assess patient satisfaction and associated factors in outpatient department of Deberebirhan Referral Hospital.

\section{Methods}

The study was carried out in Deberebirhan Referral Hospital from April 1-30, 2013. Deberebirhan Referral Hospital is one of the governmental referral hospitals in North Shoa zone which is located $130 \mathrm{~km}$ far from Addis Ababa, the capital city of Ethiopia. It provides services for around 5000 emergency cases and 103,403 outpatient attendants each year. The study utilized institution-based crosssectional study design with quantitative data collection method. Clients with greater than 15 year's age coming to the outpatient departments

*Corresponding author: Measho Gebreslassie Gebregziabher, Department of Health Service Management and Health Economics, Institute of Public Health, University of Gondar, Gondar, Ethiopia, Tel: +251-918-153731; E-mail: measho2013@gmail.com

Received September 13, 2014; Accepted October 06, 2014; Published October 16, 2014

Citation: Mezemir R, Getachew D, Gebreslassie M (2014) Patients Satisfaction and its determinants in Outpatient Department of Deberebirhan Referral Hospital, North Shoa, Ethiopia. Int J Econ Manag Sci 3: 191. doi: 10.4172/2162-6359.1000191

Copyright: (c) 2014 Mezemir R, et al. This is an open-access article distributed under the terms of the Creative Commons Attribution License, which permits unrestricted use, distribution, and reproduction in any medium, provided the original author and source are credited. 
Citation: Mezemir R, Getachew D, Gebreslassie M (2014) Patients' Satisfaction and its determinants in Outpatient Department of Deberebirhan Referral Hospital, North Shoa, Ethiopia. Int J Econ Manag Sci 3: 191. doi: 10.4172/2162-6359.1000191

during the study period were selected by using systematic random sampling technique. Seriously ill patients were excluded.

The sample size was calculated using single population proportion formula with the following assumptions; proportion 43.6\% (which was obtained from patient satisfaction at Tigray Zonal Hospital), 5\% margin of error at $95 \%$ confidence level. The sample size was 416 after considering $10 \%$ non response rate. The total sample size was allocated proportionally to all out patient department services. The dependant variable was patient satisfaction; likewise the independent variables included were;socio demographic factors (age, sex, marital status, educational level, occupation, residence, frequency of visit, patient department), frequency of visit, reason for visit, payment status, waiting time, availability of drugs and supplies and other hospital service.

Waiting time: the time gap between the patient's arrival at the service delivery point and the time the patient received health service. Satisfied: In this study refers to clients who have the overall satisfaction of equal and above the mean score calculated from the satisfaction measuring items.

The questionnaires were prepared by reviewing relevant literatures. Pre- test was done on $10 \%$ of the subjects at Enat hospital. Data were collected by pre-tested, pre-coded and interviewer-administered questionnaires.The collected data were cleaned, coded, entered into EPI-INFO version 3.5.1 software and transferred and analysed using SPSS computer soft ware package version 20. Summary statistics of socio demographic variables were presented using frequency tables and graphs. Bivariate analysis was done and variables with p-value less than 0.2 were included in the multiple logistic regression analysis. Odds ratio and $95 \%$ confidence intervals were also computed along with the corresponding $\mathrm{p}$-value.

The study was reviewed and approved by Institution Research Review Boards, Institute of Public Health at the University of Gondar. The purpose and the importance of the study were explained and written consent was obtained from each participant. Moreover, confidentiality of the information was assured by using anonymous questionnaires and by keeping the data in a secured place.

\section{Results}

\section{Socio demographic characteristics of the respondents}

A total of 414 patients were enrolled in the study with a response rate of $98 \%$. Out of the total study subjects, 226 (54.6\%) were females. One hundred thirty one $(31.6 \%)$ and $98(23.7 \%)$ of the clients were in the age group of 25-34 and 35-44 years respectively. Similarly, 332 $(80.2 \%)$ and $323(78.0 \%)$ of the study subjects were orthodox in religion and Amhara in Ethnicity (Table 1).

\section{Level of patient satisfaction}

From the total of 414 respondents, 239 (57.7\%) patients were satisfied by the overall service rendered in the hospital. Majority of the patients $350(84.5 \%), 253(61.1 \%) 368(88.9 \%), 288(69.6 \%)$ were satisfied with the availability of nurses for consultation, privacy during examination, quality of medical equipments, and clean and tidy environment respectively.

\section{Factors associated patient satisfaction at outpatient department}

The result showed that age, educational status, payment status, waiting time, availability of drug and supply were found to be significantly associated with patient satisfaction in the multiple logistic regression analysis model $(\mathrm{p}<0.05)$. Patients who belong to the age group of above 45 years and did not charge for the treatment were found be 3.35 and 2.5 times more likely to be satisfied than those who were in the age group of 15-24 [AOR:3.353(1.628-6.905)] and paying for the treatment [AOR: 2.510(1.518-4.150)] respectively.

Furthermore, respondents who had higher education and spent more than two hours in the hospital before getting service were $61 \%$ and $84 \%$ less likely satisfied than those who were illiterate [AOR: $0.392(0.188-0.818)]$ and spent less than one hours in the hospitals before getting service [AOR: 0.149(0.077-0.287)] respectively.

Concerning availability of drug and supply, patients who have got all the prescribed drug in the hospital pharmacy were 4.30 times more likely to satisfied than those who did not get all the prescribe drugs in the hospital pharmacy [AOR: 4.304(1.139-14.606)] (Table 2).

\section{Discussion}

Patient satisfaction is popular way of evaluating quality of health

\begin{tabular}{|c|c|c|}
\hline Characteristics & Number $(n=414)$ & Percent (\%) \\
\hline $\begin{array}{c}\text { Male } \\
\text { Female }\end{array}$ & $\begin{array}{l}188 \\
226\end{array}$ & $\begin{array}{l}45.4 \\
54.6\end{array}$ \\
\hline $\begin{array}{c}15-24 \\
25-34 \\
35-44 \\
45+\end{array}$ & $\begin{array}{c}86 \\
131 \\
98 \\
99\end{array}$ & $\begin{array}{l}20.8 \\
31.6 \\
23.7 \\
23.9\end{array}$ \\
\hline $\begin{array}{l}\text { Marital status } \\
\qquad \begin{array}{r}\text { Single } \\
\text { Married } \\
\text { Divorced } \\
\text { Widowed }\end{array}\end{array}$ & $\begin{array}{c}104 \\
257 \\
47 \\
6\end{array}$ & $\begin{array}{c}25.1 \\
62.1 \\
11.4 \\
1.4\end{array}$ \\
\hline $\begin{array}{l}\text { Educational status } \\
\text { Not able to read and write } \\
\text { Primary } \\
\text { Secondary } \\
\text { Diploma and above }\end{array}$ & $\begin{array}{c}138 \\
82 \\
71 \\
123\end{array}$ & $\begin{array}{l}33.3 \\
19.8 \\
17.1 \\
29.7\end{array}$ \\
\hline $\begin{array}{l}\text { Occupation } \\
\qquad \begin{array}{c}\text { Civil servant } \\
\text { Self employers } \\
\text { Merchant } \\
\text { Framers } \\
\text { No job } \\
\text { Students } \\
\text { Others }\end{array}\end{array}$ & $\begin{array}{c}117 \\
15 \\
53 \\
71 \\
106 \\
49 \\
3\end{array}$ & $\begin{array}{c}28.3 \\
3.6 \\
12.8 \\
17.1 \\
25.6 \\
11.8 \\
0.7\end{array}$ \\
\hline $\begin{array}{l}\text { Orthodox } \\
\text { Muslim } \\
\text { Protestant } \\
\text { Others }\end{array}$ & $\begin{array}{c}332 \\
59 \\
19 \\
4\end{array}$ & $\begin{array}{l}80.2 \\
14.3 \\
4.6 \\
1.0\end{array}$ \\
\hline $\begin{array}{l}\text { Amhara } \\
\text { Oromo } \\
\text { Others }\end{array}$ & $\begin{array}{c}323 \\
88 \\
3\end{array}$ & $\begin{array}{c}78.0 \\
21.3 \\
0.7\end{array}$ \\
\hline Address & $\begin{array}{l}227 \\
187\end{array}$ & $\begin{array}{l}54.8 \\
45.2\end{array}$ \\
\hline $\begin{array}{c}\text { Visited Service } \\
\text { OPD } \\
\text { MCH } \\
\text { ART clinic }\end{array}$ & $\begin{array}{l}285 \\
60 \\
69\end{array}$ & $\begin{array}{l}68.8 \\
14.5 \\
16.7\end{array}$ \\
\hline $\begin{array}{l}\text { Payment status } \\
\text { Paying } \\
\text { Free }\end{array}$ & $\begin{array}{l}274 \\
140\end{array}$ & $\begin{array}{l}66.2 \\
33.8\end{array}$ \\
\hline $\begin{array}{l}\text { Frequency of visit } \\
\qquad \text { New } \\
\text { Repeat }\end{array}$ & $\begin{array}{l}180 \\
234\end{array}$ & $\begin{array}{l}43.3 \\
56.5\end{array}$ \\
\hline
\end{tabular}

Table 1: Socio demographic characteristics of patients at Deberebirhan referral hospital North Shoa, Ethiopia, April 2013 
Citation: Mezemir R, Getachew D, Gebreslassie M (2014) Patients' Satisfaction and its determinants in Outpatient Department of Deberebirhan Referral Hospital, North Shoa, Ethiopia. Int J Econ Manag Sci 3: 191. doi: 10.4172/2162-6359.1000191

Page 3 of 4

\begin{tabular}{|c|c|c|c|c|}
\hline Variable & $\square$ & & COR $(95 \% \mathrm{Cl})$ & AOR $(95 \% \mathrm{Cl})$ \\
\hline \multicolumn{5}{|l|}{ Sex } \\
\hline Male & 97 & 91 & 1 & \\
\hline Female & 142 & 84 & $1.586(1.070-2.350)$ & \\
\hline Marital status & $\mathrm{t}$ & & & \\
\hline Single & 46 & 58 & 1 & 1 \\
\hline Married & 155 & 102 & $1.916(1.209-3.037)$ & \\
\hline Divorced & 34 & 13 & $3.298(1.562-6.961)$ & \\
\hline Widowed & 4 & 2 & $2.522(0.442-14.381)$ & \\
\hline \multicolumn{5}{|l|}{ Age } \\
\hline $15-24$ & 48 & 38 & 1 & 1 \\
\hline $25-34$ & 62 & 69 & $0.711(0.412-1.229)$ & $0.823(0.440-1.541)$ \\
\hline $35-44$ & 55 & 43 & $1.013(0.565-1.815)$ & $1.249(0.641-2.454)$ \\
\hline $45+$ & 74 & 25 & $2.343(1.258-4.364)$ & $3.353(1.628-6.905)^{\star}$ \\
\hline \multicolumn{5}{|l|}{ Educational level } \\
\hline Not able to read and write & 95 & 43 & 1 & 1 \\
\hline Primary school & 49 & 33 & $0.672(0.380-1.188$ & $0.637(0.303-1.337)$ \\
\hline Secondary school & 33 & 38 & $0.393(0.218-0.709)$ & $0.419(0.185-0.948)^{*}$ \\
\hline Diploma and above & 62 & 61 & $0.460(0.278-0.762)$ & $0.392(0.188-0.818)^{*}$ \\
\hline \multicolumn{5}{|l|}{ Occupation } \\
\hline Civil servant & $61(51.2 \%)$ & $56(47.9 \%)$ & 1 & 1 \\
\hline Self employer & $9(60 \%)$ & $6(40 \%)$ & $1.377(0.461-4.116)$ & \\
\hline Merchant & $29(54.7 \%)$ & $24(45.3 \%)$ & $1.109(0.578-2.127)$ & \\
\hline Framers & $44(62 \%)$ & $27(38 \%)$ & $1.496(0.820-2.729)$ & \\
\hline No job & $68(64.2 \%)$ & $38(35.8 \%)$ & $1.643(0.960-2.813)$ & \\
\hline Student & $26(53.1 \%)$ & $23(46.9 \%)$ & $1.038(0.532-2.024)$ & \\
\hline Others & $2(66.7 \%)$ & $1(33.3 \%)$ & $1.836(0.162-20.808)$ & \\
\hline \multicolumn{5}{|l|}{ Address } \\
\hline Urban & $132(58.1 \%)$ & $95(41.9 \%)$ & 1 & 1 \\
\hline Rural & $107(57.2 \%)$ & $80(42.8 \%)$ & $0.963(0.651-1.424)$ & \\
\hline \multicolumn{5}{|l|}{ Payment status } \\
\hline Paying & $145(52.9 \%)$ & $129(47.1 \%)$ & 1 & 1 \\
\hline Free & $94(67.1 \%)$ & $46(32.2 \%)$ & $1.818(1.189-2.781)$ & $2.510(1.518-4.150)^{*}$ \\
\hline \multicolumn{5}{|l|}{ Frequency of visit } \\
\hline New & $104(57.8 \%)$ & $76(42.2 \%)$ & 1 & 1 \\
\hline Repeat & $135(57.7 \%)$ & $99(42.3 \%)$ & $0.997(0.672-1.477)$ & \\
\hline \multicolumn{5}{|l|}{ Availability of drug andsupply } \\
\hline None & $5(27.8 \%)$ & $13(72.2 \%)$ & 1 & 1 \\
\hline Not ordered & $32(64.0 \%)$ & $18(36.0 \%)$ & $4.622(1.417-15.073)$ & $4.940(1.247-19.569)^{*}$ \\
\hline Some but not all & $47(40.9 \%)$ & $68(59.1 \%)$ & $1.797(0.600-5.397)$ & $1.476(0.422-5.158)$ \\
\hline All of them & $155(67.1 \%)$ & $76(32.9 \%)$ & $5.303(1.824-15.417)$ & $4.304(1.268-14.606)^{\star}$ \\
\hline \multicolumn{5}{|l|}{ Waiting time } \\
\hline Less than one hour & & & 1 & 1 \\
\hline One to two hours & & & $0.262(0,165-0.417)$ & $0.230(0.139-0.380)^{*}$ \\
\hline Greater than two hours & & & $0.150(0.83-0.272)$ & $0.149(0.077-0.287)^{\star}$ \\
\hline
\end{tabular}

Table 2: Multivariate Analysis showing factors associated with patient satisfaction

services in most developed countries. It has been also practiced in developing countries like Ethiopia.

This study revealed that the overall patient satisfaction at Deberebirhan Referral Hospital was $57.1 \%$. This finding is lower than study conducted in Trinidad, Tobago, Nigeria, Kuwait and Bangladesh in which the patient satisfaction was $74 \%$ and $84 \% 94,2 \%, 99.6 \%$ and $68 \%$ respectively [14-16]. The observed difference might be due to adequate number of health professionals, good infrastructure and better diagnostic facilities studies in most developed countries. However, the patient satisfaction in Deberebirhan Referral Hospital was higher than study conducted in selected hospitals of Amhara region, Tigray zonal hospital, hospitals in central Ethiopia and Harar hospital in which the patient satisfaction was $22 \%$ to $50 \%, 43.6 \%, 54.1 \%$ and $54.1 \%$ respectively [17-20]. This might due the fact many efforts have been made to make changes in the service delivery process. In addition, health workers might be highly motivated to attain higher patients' needs and make the hospital as a good model of the regional referral hospitals.

This study showed that lower educational status and older age were significantly associated with patient satisfaction [21]. This is in agreement with the study Jimma specialized and teaching hospital, Tukmur and Bangladesh More than $68 \%$ of the patients were getting prescribed drugs within the hospital pharmacy. The finding is not in line with studies done elsewhere (20212829) in Ethiopia. Majority $54.1 \%$ 
Citation: Mezemir R, Getachew D, Gebreslassie M (2014) Patients' Satisfaction and its determinants in Outpatient Department of Deberebirhan Referral Hospital, North Shoa, Ethiopia. Int J Econ Manag Sci 3: 191. doi: 10.4172/2162-6359.1000191

of the respondents were not satisfied with the physical environment, which is in line with study done in Bangladesh. Similarly, more than $40 \%$ of the study subjects were not satisfied with the waiting time. This is similar with study done in Tigray zonal hospital

\section{Limitation of the study}

Since the study was institutional based, underestimating patient satisfaction could be there. It is possible that a dissatisfied patient may not come to the hospital. Response bias might be also introduced, though we tried to reduce it.

\section{Conclusion}

The overall patient satisfaction in Deberebirhan referral hospital was $57.7 \%$ which was high as compared to different studies in Ethiopia. Majority of the patients $54.1 \%$ were not satisfied with physical environment (availability drinking water and cleanness of the toile). From the social demographic characteristics, educational status, payment status of the patient and age were significantly associated of patient satisfaction. Majority of the patients were not satisfied with waiting time and lack of drug and supply.

\section{Recommendations}

Deberebirhan Referral hospital management bodies should give attention to the physical cleanness of the hospital, patient waiting time, service payment to improve their patients' satisfaction. Amhara Regional Health Bureau should look for different mechanisms to enable the hospitals keep adequate stock of essential drugs and supplies. Researchers need to conduct further research by adding different explanatory variable like attitude and expectation of the patient about the problem

\section{Acknowledgment}

We deeply express our gratefulness to University of Gondar for financial support without which this project would have not been possible. Our special thanks and sincere appreciation also goes to Deberebirhan Referral Hospital workers, data collectors and study subjects.

\section{Authors' contributions}

RM conceived the original idea, involved in proposal writing, designed the study and participated in all implementation stages of the project. MG analyzed the data and finalized the write up of the manuscript. MG was responsible for critically revising the proposal and the manuscript, and participated in its design and interpretation. MG and RM were responsible for data collection, initial analysis and drafting of manuscript. Both authors reviewed and approved the final manuscript.

\section{Disclosure}

The authors declare that they have no competing interests.

\section{References}

1. Staniszewska S, Ahmed L (1998) Patient expectations and satisfaction with health care. Nurs Stand $12: 34-38$.
2. Youssef FN, Nel D, Bovaird T (1996) Health care quality in NHS hospitals. Int J Health Care Qual Assur 9: 15-28.

3. Lim PC, Tang NK (2000) A study of patients' expectations and satisfaction in Singapore hospitals. Int J Health Care Qual Assur Inc Leadersh Health Serv 13: $290-299$.

4. FRACP SSW (2002) Customer Satisfaction and Health Care Delivery Systems. The Int $\mathrm{J}$ Health 3.

5. D.Andrew Lo, Andrea B, Bunston T (1999) Development and Testing of a VisitSpecific Patient Satisfaction Questionnaire: The Princess Margaret Hospital Satisfaction With Doctor Questionnaire. J Clin Oncol 17: 1931-8.

6. Alzolibani AA (2011) Patient satisfaction and expectations of the quality of service of University affiliated dermatology clinics. J Public Health and Epidem 3: 61-7.

7. Bernhart MH, Wiadnyana IG, Wihardjo H, Pohan I (1999) Patient satisfaction in developing countries. Soc Sci Med 48:989-96.

8. Jager Jd (2001) service quality percipation and patient satisfaction. A study of hospital n developing contry Soc Sci Med 52: 1359-1370.

9. Mathew S, Beth E (2001) To Assessing Client Satisfaction. Durban, (South Africa). Health system Trust.

10. Prasanna K, Bashith M, Sucharitha S (2009) Consumer Satisfaction about Hospital Services: A Study from the Outpatient Department of a Private Medical College Hospital at Mangalore. Indian J Community Med 34: 156-9.

11. Mendoza Aldana J, Piechulek H, al-Sabir A (2001) Client satisfaction and quality of health care in rural Bangladesh. Bull World Health Organ 79: 512-517.

12. Ethiopia FDRo, Health Mo. Ethiopia hospital reform implementation guideline 2010; 1.

13. Andaleeb SS (2001) Service quality perceptions and patient satisfaction: a study of hospitals in a developing country. Soc Sci Med 52: 1359-1370.

14. Zineldin M (2006) The quality of health care and patient satisfaction: an exploratory investigation of the $5 \mathrm{Qs}$ model at some Egyptian and Jordanian medical clinics. Int J Health Care Qual Assur Inc Leadersh Health Serv 19: 60-92.

15. Singh H, Haqq ED, Mustapha N (1999) Patients' perception and satisfaction with health care professionals at primary care facilities in Trinidad and Tobago. Bull World Health Organ 77: 356-360.

16. Al-Eisa IS, Al-Mutar MS,Radwan MM, Al-Terkit AM (2005) Patients' Satisfaction with Primary Health Care Services at Capital Health Region, Kuwait. Middle East Journal of Family Medicine 3.

17. Birhanu Z, Assefa T, Woldie M, Morankar S (2010) Determinants of satisfaction with health care provider interactions at health centres in central Ethiopia: a cross sectional study. BMC Health Serv Res 10: 78.

18. Abdosh B (2006) The quality of hospital services in eastern Ethiopia: Patient's perspective. Ethiop J Health Dev 20:199-200.

19. Adane G (2006) Assessment of clients' satisfaction with outpatient services BioMed Central.

20. Dagnew M, Zakus D (1997) Community perception on OPD performance of a teaching hospital in Gondar town. Ethiop Med J 35: 153-160.

21. Mohammad Jasim Uddin LA (2011) Factors Determining Inpatient Satisfaction with Hospital Care in Bangladesh. Asian Social Science 7. 